\title{
Prevalence of endothelial nitric oxide synthase (ENOS) gene G894T polymorphism and its association with hypertension: a population-based study with Brazilian women
}

Abel Barbosa Lira Neto ${ }^{1,2}$, Myrla C. O. Farias ${ }^{1,2}$, Nancy B. R. Vasconcelos ${ }^{1}$, Antonio F. Xavier Jr², Monica L. Assunção ${ }^{1}$, Haroldo S. Ferreira ${ }^{1}$

\begin{abstract}
${ }^{1}$ Faculty of Nutrition, Federal University of Alagoas, Maceió, AL, Brazil ${ }^{2}$ Postgraduate Program in Health Sciences of the Institute of Biological and Health Sciences, Federal University of Alagoas, Maceió, AL, Brazil
\end{abstract}

Submitted: 4 December 2018

Accepted: 18 March 2019

Arch Med Sci Atheroscler Dis 2019; 4: e63-e73

DOI: https://doi.org/10.5114/amsad.2019.84539

Copyright (c) 2019 Termedia \& Banach

\section{Abstract}

Introduction: Hypertension is one of the most prevalent diseases in the world, accounting for millions of deaths each year. The reduction in the concentration of nitric oxide (NO) produced by the catalysis of endothelial nitric oxide synthase (eNOS) is associated with higher blood pressure (BP) levels. This reduction might be because of genetic polymorphisms. This study investigated the prevalence of the eNOS gene G894T polymorphism in women from northeast Brazil and its association with hypertension.

Material and methods: This cross-sectional study included 810 women (aged 19-49 years). Sociodemographic, health, anthropometric, and BP data were collected. Hypertension was defined according to the following criteria: systolic $B P \geq 140 \mathrm{~mm} \mathrm{Hg}$, diastolic $B P \geq 90 \mathrm{~mm} \mathrm{Hg}$, the regular use of antihypertensive medication, or some combination thereof. Epithelial cells from the cheek mucosa were obtained for DNA extraction. Genotyping was performed via real-time PCR. The measure of association was the prevalence ratio (PR) and its $95 \% \mathrm{Cl}$ as calculated via Poisson regression.

Results: The frequencies of the GG, GT, and TT genotypes were $57.1 \%, 35.7 \%$, and $7.2 \%$, respectively. For each of these genotypes, the prevalence of hypertension in women was $17.9 \%, 23.6 \%$, and $34.4 \%$, respectively. Relative to the GG genotype, the PRs after adjusting for cofounding factors were 1.24 (95\% Cl: $0.95-1.61, p=0.11$ ) for GT and 1.76 (95\% Cl: $1.16-2.67, p<0.01)$ for TT. Conclusions: The $T$ allele of the G894T polymorphisms is associated with hypertension in women. This may have implications for prevention and treatment.

Key words: nitric oxide, nitric oxide synthase, hypertension.

\section{Introduction}

Hypertension is one of the most prevalent diseases in the world, accounting for 9.4 million deaths each year [1]. This condition is often associated with metabolic disorders as well as functional and structural alterations of target organs. Furthermore, it is aggravated by the presence of other risk factors such as dyslipidemia, abdominal obesity, glucose intolerance, and diabetes [2].

\author{
Corresponding author: \\ Haroldo da Silva Ferreira \\ Faculty of Nutrition \\ Federal University \\ of Alagoas \\ Av. Pilar 550 \\ Cruz das Almas \\ 57038-430 Maceió \\ Alagoas, Brazil \\ Phone: +55 $8298853-8243$ \\ E-mail: \\ haroldo.ufal@gmail.com
}


Because of its high prevalence and multifactorial etiology, it is important to understand the dynamics of the risk factors associated with hypertension, especially the hereditary component, which might explain approximately $45 \%$ of all cases of high blood pressure (BP) [3]. Thus, research interest regarding identification of the genetic polymorphisms associated with hypertension has grown [4]. These polymorphic differences include those of the gene of the endothelial nitric oxide synthase (eNOS) enzyme, which is involved in the production of nitric oxide (NO) from the oxidation of $\mathrm{L}$-arginine. The $\mathrm{NO}$ is a free radical that acts in the vasodilation process and regulation of vascular tone $[5,6]$.

In knockout animal models in which genetic manipulation was performed to inhibit expression of the eNOS gene (eNOS-KO), an increase in BP levels was observed, demonstrating the importance of NO in the regulation of blood pressure [7, 8].

In addition to BP control, $\mathrm{NO}$ is also related to lipid metabolism via inhibition of LDL oxidation and the platelet aggregation resulting from this oxidation [9]. Thus, NO is an important protective factor against the progression of cardiovascular diseases [10].

Of the polymorphisms associated with the eNOS gene, G894T is the most scientifically relevant because it has been recognized as an important risk factor regarding the increase of $\mathrm{BP}$ levels and the occurrence of other diseases such as coronary artery disease, vascular diseases, acute myocardial infarction, metabolic syndrome, and type 2 diabetes [11]. In a study of Caucasian individuals from the Iberian peninsula, Goni et al. found a significantly higher DBP of $1.99 \mathrm{~mm} \mathrm{Hg}$ in the people with the GT or TT genotypes compared with those with the GG genotype [12].

Therefore, the G894T polymorphism, by directly influencing eNOS gene expression, is an important biomarker for the development of hypertension [9]. However, no studies have described the distribution and association of the G894T polymorphism with regard to hypertension in women from northeast Brazil, a region characterized by greater social vulnerability and (in relation to the South/Southeast regions) the worst social indicators in the country. This investigation is important because gene expression can be strongly influenced by environmental factors [13].

In addition to the environmental question, hypertension has different effects according to gender, as noted by the National Health Survey in 2013, which observed a higher prevalence of hypertension among women (24.2\% vs. $18.3 \%$ ) [14].

The present study sought to characterize the distribution of the G894T polymorphism of the eNOS gene in a population of women from north- east Brazil and investigate its association with hypertension.

\section{Material and methods}

This is a cross-sectional study involving a representative sample of women from Alagoas, a state in northeastern Brazil, whose general population is estimated at about three million inhabitants [15].

For the sample size calculation, the variable of interest was hypertension, whose prevalence in Brazilian adults was estimated to be $23.3 \%$ [16]. Given a population of 718,493 women aged 19 to 49 years, a sample error of $3.0 \%$, and a confidence interval $(\mathrm{Cl})$ of $95 \%$, the study would require a sample of 762 women. To cover any potential sample losses, an additional $10 \%$ was added to this number. Thus, the planned sample was 838 women. The calculations were performed using the StatCalc module of Epi Info 7.1.4 (CDC, Atlanta, USA).

To attain the required number of women, a multiple stage process was adopted across four steps. In the first stage, 30 of the 102 municipalities in Alagoas were selected via random sampling with a probability proportional to the number of inhabitants. Because of its larger population, Arapiraca was selected twice, and Maceió, the state capital, which contains a third of the population of Alagoas, was sampled ten times. In the second step, four census tracts per municipality were chosen via a simple drawing, respecting the proportion between urban and rural sectors. For the cities of Maceió and Arapiraca, the census sectors were organized in a list, and the drawing was performed using systematic sampling. In the third step, one block in each census tract was randomly selected; finally (step 4), a starting point (i.e., a corner) in each block was randomly chosen, from which seven consecutive households were visited moving in a counterclockwise direction. Women aged 20 to 49 years old who resided in the selected households were eligible for this study.

\section{Dependent variable}

The dependent variable was systemic hypertension. BP was measured in duplicate, with the individual seated after 15 min of rest using Omron HEM-7113 digital BP monitors (Omron, Tokyo, Japan). Systemic hypertension was diagnosed when systolic BP (SBP) was $\geq 140 \mathrm{~mm} \mathrm{Hg}$, diastolic BP (DBP) was $\geq 90 \mathrm{~mm} \mathrm{Hg}$, when the patient reported the use of antihypertensive medications, or some combination thereof [17].

\section{Independent variable}

The independent variable was the G894T polymorphism of the eNOS gene according to the $G G$, GT, and TT genotypes. 
During the household visits, the women were invited to be present the next day at a predetermined location near their household (a basic health unit or a school, for example), where, in addition to biochemical tests, oral mucosa cells were collected. The patients were instructed to pre-rinse with $100 \mathrm{ml}$ of distilled water, and the collection was performed by scraping the inner cheeks with small sterile cytology brushes, making approximately 30 circular movements. The outer portions of the brushes were cut and placed in 2-ml microtubes. The samples obtained were stored in a refrigerator for subsequent DNA extraction with $\mathrm{NaCl}$ [18]. The DNA was then quantified using a spectrophotometer. After extraction and quantification, the DNA samples were stored at $-24^{\circ} \mathrm{C}$ until genotyping was performed.

The 894G>T (rs1799983) polymorphism has the sequence TTCCTGCTGCAGGCCCAGTGA[G/T] CCCCCAGAACTCTTCCTTCTGCCC and was genotyped using the TaqMan Genotyping Assay method (Applied Biosystems, Foster City, CA, USA). $P C R$ reactions were performed with $5.0 \mu \mathrm{l}$ of 2X TaqMan Genotyping Master Mix, $0.125 \mu \mathrm{l}$ of TaqMan 40X Assay, and $4.87 \mu \mathrm{l}$ of $4 \mathrm{ng} / \mu \mathrm{l}$ DNA to a final volume of $10 \mu \mathrm{l}$. The amplification parameters consisted of $95^{\circ} \mathrm{C}$ for $10 \mathrm{~min}$, followed by 40 cycles at $92^{\circ} \mathrm{C}$ for $15 \mathrm{~s}$, and $60^{\circ} \mathrm{C}$ for 1 min using the Step One Plus Real-Time PCR System (Applied Biosystems, Foster City, CA, USA). Individual genotypic discrimination was performed using Step One Plus software, version 2.3, at the end of each reaction. Positive controls and negative controls were used to avoid possible contamination for all reactions.

\section{Covariates (variables analyzed to control for confounds, to characterize the sample, or both)}

The following variables were obtained: age; location of residence (rural or urban); employment; schooling; skin color/ethnicity; parity; beneficiary of the "Bolsa Família" Program; access to health services (public or private); and food security status; prevalence of disease over the last 15 days; regular alcohol consumption; smoking status; physical activity level; regular consumption of chicken skin; regular consumption of high-fat meats; consumption of added salt; body mass index; waist circumference; total cholesterol, low-density lipoproteins (LDL) and high-density lipoproteins (HDL); triglycerides; and blood glucose [19].

\section{Data processing and analysis}

The data were entered independently in duplicate into an electronic form generated with Epi Info 7.1.4 (CDC, Atlanta, USA), which enabled the identification and correction of possible typing errors.

Hardy-Weinberg equilibrium (HWE) was determined with the $\chi^{2}$ test $(p>0.05)$. This procedure was necessary to certify that the sample complied with the principles of population genetics and as a control measure of the accuracy of the genotype analyses.

The analysis was performed according to the theoretical model adapted from Sturmer [20] (Figure 1) using two approaches. In the first approach, the dependent variable was hypertension (categorical variable). In the second approach, the dependent variables were SBP and DBP, analyzed as continuous variables. In both situations, the hierarchical analyses were composed of four levels: The first level included the demographic and socioeconomic variables; level 2 included the variables related to lifestyle and dietary factors; level 3 included the anthropometric and biochemical indicators; and level 4 included the associations with the eNOS gene polymorphisms. Level 2 was adjusted by the variables with $p<0.05$ at level 1 ; level 3 was adjusted by the variables with $p<0.05$ at levels 1 and 2; and level 4 was adjusted by all variables with $p<0.05$ at the previous levels.

To identify the association between hypertension and the GG, GT, and $T T$ genotypes of the eNOS gene G894T polymorphism, the prevalence ratio (PR) and its 95\% confidence intervals (Cls) calculated via the Poisson regression were used.

All of the covariates that were associated with hypertension in the basic analysis at a significance level of up to $20 \%(p<0.2)$ were eligible for the hierarchical analysis. Non-significant variables were successively eliminated for each of the four levels of hierarchical analysis (backward stepwise), leaving only those with $p<0.05$. From this definition, all of these variables remained in the final adjusted model, even if they lost significance at the levels following their original level to control for possible confounds.

To confirm the association between BP levels and the GG, GT, and $T T$ genotypes, a multiple linear regression analysis was used according to the theoretical model defined for the hierarchical analysis. The procedures for variable inclusion and exclusion were identical to those described above for the Poisson regression analysis. For this approach, the standardized angular coefficients (SACS) were calculated to estimate the increases in blood pressure ( $\mathrm{mm} \mathrm{Hg}$ ) according to the different variables introduced in the model. Stata/SE 12.1 for Windows (StataCorp LP, College Station, TX, USA) was used for all statistical analyses. This study was approved by the Research Ethics Committee of the Federal University of Alagoas (Case $n^{\circ}$ 09093012.0.0000.5013). 


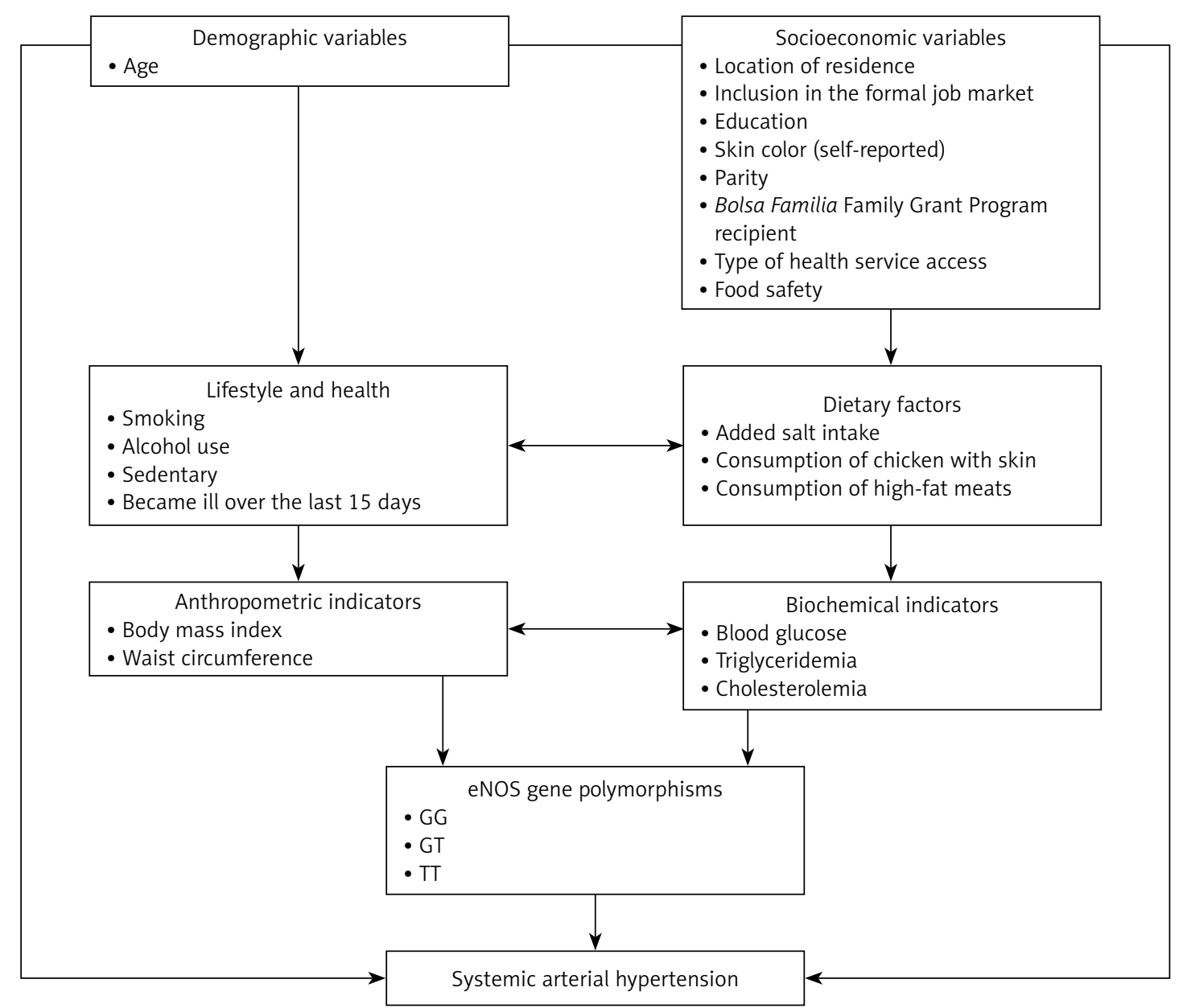

Figure 1. Hierarchical conceptual mode of systemic hypertension (adapted from Stunner et al., 2006)

\section{Results}

A total of 887 women eligible were identified for this study. Of these, 40 (4.5\%) were not at home at the time of the interview or refused to participate in the study. In addition, women who did not provide data regarding age $(n=4,0.9 \%)$, anthropometric indices $(n=7,0.8 \%)$, or BP measurements $(n=7 ; 0.8 \%)$ as well as those from whom it was not possible to extract DNA ( $n=19$; $2.1 \%$ ) were excluded from the analyses. Therefore, the final sample consisted of 810 women $(35.8$ \pm 8.4 years).

The socioeconomic, demographic, lifestyle, anthropometric, biochemical, and genetic variables of the sample are described in Table I. The majority of the sample was of black or brown color/race (75.9\%), had up to 8 years of education (58.2\%), and had no formal employment $(74.5 \%)$ at the time of the interview.

Regarding health conditions, $65.1 \%$ of the women reported they were not ill over the last 15 days. Of those who were ill, $91.2 \%$ claimed to seek care from public health services. The prevalence of hypertension was $21.1 \%$. Only $8.9 \%$ of the women were smokers, but $31.6 \%$ reported alcohol consumption. According to $\mathrm{BMI}, 66.1 \%$ were overweight $\left(\geq 30 \mathrm{~kg} / \mathrm{m}^{2}\right)$.

The minor allele was $T$ (24.9\%), and the genotypic frequencies for the G894T polymorphism were $G G=57.1 \%(n=463), G T=35.7 \%(n=289)$ and $T T=7.2 \%(n=58)$.

The polymorphism distribution conformed to the HWE, with $p=0.16$ indicating that the sample population used was in HWE.

Comparing the GG, GT, and TT genotypes, the rates of systemic hypertension were $13.4 \%$, $19.1 \%$, and $32.7 \%$, respectively. Compared with the prevalence of the GG genotype (13.4\%), the PRs for the GT and TT genotypes were 1.24 (95\% Cl: $0.95-1.61 ; p=0.11)$ and $1.76(95 \% \mathrm{Cl}$ : 1.16-2.67; $p<0.01$ ), respectively (Table II).

Lipid and glycemic disorders were not significant risk factors for systemic hypertension. After an adjusted analysis, the factors that were significantly associated with hypertension were age $\geq 30$ years old, residing in a rural area, education $\leq 8$ years, having three or more children, being overweight $\left(\mathrm{BMI} \geq 25 \mathrm{~kg} / \mathrm{m}^{2}\right)$, and having a large waist circumference. Compared with the GG geno- 
Table I. Distribution of hypertension according to socioeconomic, demographic, lifestyle, anthropometric, biochemical, and genetic variables. Women from Alagoas, Brazil $(n=851), 2015$

\begin{tabular}{|c|c|c|c|}
\hline Variables & $n(\%)$ & Hypertension (\%) & $P$-value \\
\hline \multicolumn{4}{|l|}{ Age group [years]: } \\
\hline $19-30$ & $257(31.7)$ & 7.7 & - \\
\hline $31-40$ & $274(33.8)$ & 17.1 & $<0.01$ \\
\hline $41-49$ & $277(33.5)$ & 37.5 & $<0.01$ \\
\hline \multicolumn{4}{|l|}{ Location of residence: } \\
\hline Urban & $639(78.8)$ & 19.7 & - \\
\hline Rural & $171(21.2)$ & 26.3 & 0.05 \\
\hline \multicolumn{4}{|l|}{ Unemployed: } \\
\hline No & $207(25.5)$ & 17.9 & - \\
\hline Yes & $603(74.5)$ & 22.2 & 0.2 \\
\hline \multicolumn{4}{|l|}{ Education [years]: } \\
\hline$>8$ & $340(41.8)$ & 14.7 & - \\
\hline$\leq 8$ & $470(58.2)$ & 25.8 & $<0.01$ \\
\hline \multicolumn{4}{|l|}{ Skin color (self-reported): } \\
\hline Not black or brown & $193(24.1)$ & 19.1 & - \\
\hline Black or brown & $608(75.9)$ & 22.1 & 0.39 \\
\hline \multicolumn{4}{|l|}{ Parity: } \\
\hline One or two children & $430(59.5)$ & 18.8 & - \\
\hline Three or more & $292(40.5)$ & 27.4 & $<0.01$ \\
\hline \multicolumn{4}{|l|}{ Access to health services: } \\
\hline Private system & $68(8.7)$ & 13.4 & - \\
\hline Public healthcare system & $708(91.2)$ & 22.4 & 0.08 \\
\hline \multicolumn{4}{|l|}{ Supplementary income: } \\
\hline Yes & $461(56.8)$ & 21.7 & \\
\hline No & $348(43.2)$ & 20.4 & 0.67 \\
\hline \multicolumn{4}{|l|}{ Food security: } \\
\hline Food security (0) & $254(33.4)$ & 17.3 & \\
\hline Food insecurity $(\geq 1)$ & $505(66.6)$ & 23.1 & 0.06 \\
\hline \multicolumn{4}{|l|}{ Became ill over the last 15 days: } \\
\hline No & $283(34.9)$ & 19.6 & - \\
\hline Yes & $526(65.1)$ & 24.1 & 0.14 \\
\hline \multicolumn{4}{|l|}{ Alcohol consumption: } \\
\hline No & $554(68.4)$ & 20.5 & - \\
\hline Yes & $256(31.6)$ & 23.5 & 0.31 \\
\hline \multicolumn{4}{|l|}{ Smoking: } \\
\hline No & $738(91.1)$ & 20.2 & \\
\hline Yes & $72(8.90)$ & 30.5 & 0.03 \\
\hline \multicolumn{4}{|l|}{ Physical activity: } \\
\hline Active $>150 \mathrm{~min} /$ week & $541(68.7)$ & 18.7 & \\
\hline Sedentary $\leq 150 \mathrm{~min} /$ week & $246(31.3)$ & 22.4 & 0.23 \\
\hline
\end{tabular}


Table I. Cont.

\begin{tabular}{|c|c|c|c|}
\hline Variables & $n(\%)$ & Hypertension (\%) & $P$-value \\
\hline \multicolumn{4}{|l|}{ Added salt intake: } \\
\hline No & $684(84.4)$ & 22.5 & \\
\hline Yes & $126(15.6)$ & 13.4 & 0.02 \\
\hline \multicolumn{4}{|l|}{ Remove skin from chicken: } \\
\hline Yes & $728(89.9)$ & 21.1 & \\
\hline No & $81(10.1)$ & 19.7 & 0.76 \\
\hline \multicolumn{4}{|l|}{ Eat high-fat meats: } \\
\hline No & $553(68.2)$ & 20.9 & \\
\hline Yes & $257(31.8)$ & 21.4 & 0.86 \\
\hline \multicolumn{4}{|l|}{ BMI classification $\left[\mathrm{kg} / \mathrm{m}^{2}\right]$ : } \\
\hline Normal $(18.5$ to < 25$)$ & $255(31.6)$ & 9.4 & - \\
\hline Overweight $(\geq 25$ to $<30)$ & $293(36.4)$ & 20.4 & $<0.01$ \\
\hline Obese $(\geq 30)$ & $243(29.7)$ & 35.4 & $<0.01$ \\
\hline \multicolumn{4}{|l|}{ Waist circumference: } \\
\hline Normal $(<0.80)$ & $320(40.6)$ & 10.9 & \\
\hline Increased $(\geq 0.80)$ & $467(59.4)$ & 29.1 & $<0.01$ \\
\hline \multicolumn{4}{|l|}{ Blood glucose [mg/dl]: } \\
\hline Normal $(\leq 99)$ & $549(83.6)$ & 19.8 & \\
\hline High ( $\geq 100)$ & $107(16.4)$ & 30.8 & $<0.01$ \\
\hline \multicolumn{4}{|l|}{ Triglycerides [mg/dl]: } \\
\hline Normal $(<150)$ & $454(69.1)$ & 18.2 & \\
\hline High ( $\geq 150)$ & $203(30.9)$ & 29.7 & $<0.01$ \\
\hline \multicolumn{4}{|l|}{ Total cholesterol [mg/dl]: } \\
\hline Normal (<190) & $342(52.1)$ & 17.8 & \\
\hline High ( $\geq 190)$ & $315(47.9)$ & 20.6 & 0.01 \\
\hline \multicolumn{4}{|l|}{ LDL-C [mg/dl]: } \\
\hline Normal $(<130)$ & $390(62.9)$ & 21.8 & \\
\hline High ( $\geq 130)$ & $230(37.1)$ & 23.4 & 0.56 \\
\hline \multicolumn{4}{|l|}{$\mathrm{HDL}-\mathrm{C}[\mathrm{mg} / \mathrm{dl}]:$} \\
\hline Normal $(\geq 40)$ & $357(54.4)$ & 19.3 & \\
\hline Low $(<40)$ & $299(45.6)$ & 24.5 & 0.1 \\
\hline \multicolumn{4}{|l|}{ Alleles: } \\
\hline $\mathrm{G}$ & $1215(75.1)$ & 14.8 & \\
\hline $\mathrm{T}$ & $405(24.9)$ & 22.7 & $<0.01$ \\
\hline \multicolumn{4}{|l|}{ Genotype: } \\
\hline$\overline{G G}$ & $463(57.1)$ & 13.4 & - \\
\hline$\overline{G T}$ & $289(35.7)$ & 19.1 & 0.36 \\
\hline TT & $58(7.2)$ & 32.7 & $<0.01$ \\
\hline
\end{tabular}


Table II. Prevalence ratios (PRs) and their respective 95\% confidence intervals $(95 \% \mathrm{Cl})$ adjusted in the multivariable Poisson regression according to the hierarchical theoretical model of the determinants of hypertension. Women from Alagoas, Brazil, 2015

\begin{tabular}{|c|c|c|c|c|c|c|c|c|}
\hline Variables & $\begin{array}{c}\text { Level } 1 \\
\text { PR } \\
(95 \% \mathrm{Cl})\end{array}$ & $P$-value & $\begin{array}{c}\text { Level } 2 \\
\text { PR } \\
(95 \% \mathrm{Cl})\end{array}$ & $P$-value & $\begin{array}{c}\text { Level } 3 \\
\text { PR } \\
(95 \% \mathrm{Cl})\end{array}$ & $P$-value & $\begin{array}{c}\text { Level } 4 \\
\text { PR } \\
(95 \% \mathrm{Cl})\end{array}$ & $P$-value \\
\hline \multicolumn{9}{|l|}{ Level 1: } \\
\hline $\begin{array}{l}\text { Age group: } \\
\geq 30 \text { years }\end{array}$ & $\begin{array}{c}2.21 \\
(1.82-2.68)\end{array}$ & $<0.01$ & $\begin{array}{c}2.19 \\
(1.80-2.66)\end{array}$ & $<0.01$ & $\begin{array}{c}1.91 \\
(1.56-2.35)\end{array}$ & $<0.01$ & $\begin{array}{c}1.58 \\
(1.68-2.51)\end{array}$ & $<0.01$ \\
\hline $\begin{array}{l}\text { Living in a rural } \\
\text { area }\end{array}$ & $\begin{array}{c}1.57 \\
(1.18-2.08)\end{array}$ & $<0.01$ & $\begin{array}{c}1.58 \\
(1.19-2.09)\end{array}$ & $<0.01$ & $\begin{array}{c}1.45 \\
(1.11-1.93)\end{array}$ & $<0.01$ & $\begin{array}{c}1.42 \\
(1.07-1.90)\end{array}$ & 0.02 \\
\hline $\begin{array}{l}\text { Education: } \\
\leq 8 \text { years }\end{array}$ & $\begin{array}{c}1.35 \\
(1.01-1.82)\end{array}$ & 0.04 & $\begin{array}{c}1.34 \\
(1.01-1.81)\end{array}$ & 0.04 & $\begin{array}{c}1.29 \\
(0.97-1.73)\end{array}$ & 0.08 & $\begin{array}{c}1.29 \\
(0.97-1.75)\end{array}$ & 0.08 \\
\hline $\begin{array}{l}\text { Parity: } \\
\geq 3 \text { children }\end{array}$ & $\begin{array}{c}0.94 \\
(0.71-1.24)\end{array}$ & 0.69 & * & * & * & * & * & * \\
\hline $\begin{array}{l}\text { Access to } \\
\text { health services: } \\
\text { public }\end{array}$ & $\begin{array}{c}1.61 \\
(0.83-3.11)\end{array}$ & 0.15 & * & * & * & * & * & * \\
\hline Food insecurity & $\begin{array}{c}1.13 \\
(0.83-1.53)\end{array}$ & 0.41 & * & * & * & * & * & * \\
\hline \multicolumn{9}{|l|}{ Level 2: } \\
\hline $\begin{array}{l}\text { Became ill over } \\
\text { the last } 15 \text { days }\end{array}$ & - & - & $\begin{array}{c}1.08 \\
(0.84-1.39)\end{array}$ & 0.51 & * & * & * & * \\
\hline $\begin{array}{l}\text { Added salt } \\
\text { intake }\end{array}$ & - & - & $\begin{array}{c}0.66 \\
(0.42-1.03)\end{array}$ & 0.07 & * & * & * & * \\
\hline Smoking & - & - & $\begin{array}{c}1.17 \\
(0.81-1.69)\end{array}$ & 0.38 & * & * & * & * \\
\hline \multicolumn{9}{|l|}{ Level 3: } \\
\hline $\begin{array}{l}\text { Overweight } \\
\left(\mathrm{BMI} \geq 25 \mathrm{~kg} / \mathrm{m}^{2}\right)\end{array}$ & - & - & - & - & $\begin{array}{c}1.37 \\
(1.10-1.71)\end{array}$ & $<0.01$ & $\begin{array}{c}1.37 \\
(1.10-1.71)\end{array}$ & $<0.01$ \\
\hline $\begin{array}{l}\text { Waist } \\
\text { circumference } \\
\geq 80 \mathrm{~cm}\end{array}$ & - & - & - & - & $\begin{array}{c}1.80 \\
(1.08-2.99)\end{array}$ & 0.02 & $\begin{array}{c}1.79 \\
(1.07-2.98)\end{array}$ & 0.02 \\
\hline $\begin{array}{l}\text { Blood glucose } \\
\geq 100 \mathrm{mg} / \mathrm{dl}\end{array}$ & - & - & - & - & $\begin{array}{c}0.92 \\
(0.67-1.28)\end{array}$ & 0.64 & * & * \\
\hline $\begin{array}{l}\text { Triglycerides } \\
\geq 150 \mathrm{mg} / \mathrm{dl}\end{array}$ & - & - & - & - & $\begin{array}{c}1.16 \\
(0.88-1.54)\end{array}$ & 0.28 & * & * \\
\hline $\begin{array}{l}\text { Total cholesterol } \\
\geq 190 \mathrm{mg} / \mathrm{dl}\end{array}$ & - & - & - & - & $\begin{array}{c}0.91 \\
(0.68-1.23)\end{array}$ & 0.55 & * & * \\
\hline \multicolumn{9}{|l|}{ Level 4: } \\
\hline \multicolumn{9}{|l|}{ Genotype: } \\
\hline GG & - & - & - & - & - & - & 1 & - \\
\hline GT & - & - & - & - & - & - & $\begin{array}{c}1.24 \\
(0.95-1.61)\end{array}$ & 0.11 \\
\hline $\mathrm{TT}$ & - & - & - & - & - & - & $\begin{array}{c}1.76 \\
(1.16-2.67)\end{array}$ & $<0.01$ \\
\hline
\end{tabular}

type, the adjusted PRs for the GT and TT genotype were $1.24(95 \% \mathrm{Cl}: 0.95-1.61 ; p=0.11)$ and 1.76 (95\% Cl: $1.16-2.67 ; p<0.01)$, respectively.

GT was not significantly different between hypertensive and normotensive groups, whereas the TT genotype was significantly higher in those with hypertension. The multiple regression analysis showed that both women with GT genotype and those with TT genotype had BP levels significantly higher than those observed in women with the $G G$ genotype, even after adjusting for confounds.

Specifically, compared with the GG genotype, women who had the $G T$ and $T T$ risk genotypes had increases in SBP of $2.72 \mathrm{~mm} \mathrm{Hg}(p=0.02)$ and $8.32 \mathrm{~mm} \mathrm{Hg}(p<0.01)$, respectively. In the case of DBP, the increase was $1.79 \mathrm{~mm} \mathrm{Hg}(p=0.03)$ for 
the GT genotype and $4.69 \mathrm{~mm} \mathrm{Hg}(p<0.01)$ for the TT genotype (Table III).

\section{Discussion}

The present study provides evidence that the polymorphism G894T of the eNOS gene is associated with higher BP levels and, consequently, with a higher prevalence of hypertension.

Since the first literature reports, NO has been considered of fundamental importance in the regulatory process of vascular homeostasis, with its levels being regulated by the eNOS gene. Several polymorphisms have been studied in an attempt to understand the genetic susceptibility to cardiovascular diseases [21].

A greater number of homozygous individuals (GG) were present in our study (57.2\%). In agreement with our results, a study of an Egyptian population found a higher frequency of the GG genotype $(70 \%)$ compared with GT $(22.9 \%)$ and TT (7.1\%) polymorphisms. Similar results were found in African populations [22-24].

Studies of Asian populations have also shown a predominance of the GG genotype; moreover, few or no people with the TT genotype were observed in Korea ( $n=411$; GG: $97.6 \%, G T: 19.5 \%$, and TT: 0.9\%) [25], Japan ( $n=513$; GG: $84.4 \%, G T$ : $17.4 \%$, and TT: 0.0\%) [25], and India ( $n=105$; GG: 74.3\%, GT: $25.7 \%$, and TT 0\%) [26] .

Our study found an association between systemic hypertension and risk factors such as age, location of residence, overweight, and waist circumference. Several studies have shown that, in addition to hereditary factors, hypertension is influenced by several risk factors such as age, gender, ethnicity, overweight/obesity, alcohol consumption, sedentary lifestyle, and socioeconomic factors [14, 27, 28].

The prevalence of hypertension in women in Alagoas (21.1\%) was similar to the estimated value for the Northeast region (19.4\%) and Brazil in general (24.2\%) [29].

In the current sample, the presence of the TT genotype was associated with a greater predisposition toward systemic hypertension. Evidently, these women also have higher BP levels than those with the GG genotype. For those with the GT genotype, the differences between the rates of hypertension were not significant. However, as with those who carried the TT genotype, they had higher BP levels than the reference genotype. Therefore, these data show that the presence of the $T$ allele is an important risk factor for hypertension.

A recent meta-analysis of 63,258 participants showed that those with the T allele for the G894T polymorphism of the eNOS gene showed a significant risk for systemic hypertension com- pared with individuals with the $G$ allele ( $G$ vs. $T$, $p<0.00001, \mathrm{OR}=0.82,95 \% \mathrm{Cl}: 0.76-0.89)$ [30].

In another meta-analysis of 45,287 individuals, the $T$ allele of the G894T polymorphism was positively associated with hypertension $(O R=1.20$; $p=0.015$ ) [31]. In addition to hypertension, reports have linked the G894T polymorphism of the eNOS gene to higher rates of diseases such as ventricular hypertrophy, coronary artery disease, and deep vein thrombosis [32, 33].

As previously mentioned, the linear regression showed that the TT and GT genotypes were associated with significantly higher SBP and DBP levels, even after controlling for several confounds.

In a study of Caucasian individuals from the Iberian peninsula, Goni et al. found a significantly higher DBP of $1.99 \mathrm{~mm} \mathrm{Hg}$ in people with the GT or TT genotype compared with those with the $G G$ genotype [12].

The adjusted analysis revealed an interaction between BMI and the G894T polymorphism with regard to the modulation of SBP and DBP levels. This observation corroborates the results found by Abdel-Aziz et al. [34], who described the association between obesity and the TT genotype of the G894T polymorphism with regard to increasing the risk of developing coronary artery disease among the Egyptian population.

Different studies revealed that the presence of thymine $(T)$ instead of guanine $(G)$ at nucleotide 894 of the gene responsible for the production of eNOS alters one or more of the functional properties of the enzyme that decreases its catalytic activity and therefore compromises the production of NO $[35,36]$.

Kayhan et al. studied the effects of eNOS associated with hypertension among Turkish patients and suggested that the G894T polymorphism of the eNOS gene increases the risk of hypertension when associated with high serum levels of total cholesterol [37]. Increased serum cholesterol levels in the circulatory system lead to increased lipid oxidation, resulting in elevated BP and increased amounts of reactive oxygen species (ROS), which reduced the expression of eNOS and decreased the production of NO [38]. Furthermore, oxidative stress is a common process associated with obesity and has been associated with the eNOS gene. An animal model study suggested that a reduction in NO production leads to an increase in ROS, contributing to hypertension in obese rats [39].

The present study sampled an ethnically heterogeneous population that included individuals with European and African ancestry as well as indigenous peoples; therefore, this sample contained people with different genetic backgrounds. As such, these results should be generalized to other populations with caution (i.e., by defining to what extent the referred population is similar to 
Table III. Standardized angular coefficients (SACs) adjusted in the multivariate linear regression related to systolic and diastolic blood pressure levels according to the hierarchical theoretical model of the determinants. Women from Alagoas, Brazil ( $n=810), 2015$

\begin{tabular}{|c|c|c|c|c|c|c|c|c|}
\hline Variables & $\begin{array}{c}\text { Level } 1 \\
\text { SAC }\end{array}$ & $P$-value & $\begin{array}{c}\text { Level } 2 \\
\text { SAC }\end{array}$ & $P$-value & $\begin{array}{c}\text { Level } 3 \\
\text { SAC }\end{array}$ & $P$-value & $\begin{array}{c}\text { Level } 4 \\
\text { SAC }\end{array}$ & $P$-value \\
\hline \multicolumn{9}{|l|}{ Systolic blood pressure } \\
\hline \multicolumn{9}{|l|}{ Level 1: } \\
\hline Age group $\geq 30$ [years] & 6.601 & $<0.01$ & 6.669 & $<0.01$ & 4.418 & $<0.01$ & 4.744 & $<0.01$ \\
\hline Living in a rural area & 4.173 & $<0.01$ & 5.001 & $<0.01$ & 3.395 & $<0.01$ & 4.014 & $<0.01$ \\
\hline Education: $\leq 8$ years & 0.828 & 0.574 & * & * & * & * & * & * \\
\hline Parity: $\geq 3$ children & 1.534 & 0.311 & * & * & * & * & * & * \\
\hline Access to health services: public & 2.790 & 0.298 & * & * & * & * & * & * \\
\hline Food insecurity: $\geq 1$ & 0.136 & 0.928 & * & * & * & * & * & * \\
\hline \multicolumn{9}{|l|}{ Level 2: } \\
\hline Became ill over the last 15 days & - & - & 0.061 & 0.960 & * & * & * & * \\
\hline Salt intake & - & - & -3.123 & 0.051 & * & * & * & * \\
\hline Smoking & - & - & 0.550 & -0.202 & * & * & * & * \\
\hline \multicolumn{9}{|l|}{ Level 3: } \\
\hline Overweight (BMI $\geq 25$ kg/m²) & - & - & - & - & 3.991 & $<0.01$ & 4.171 & $<0.01$ \\
\hline Waist circumference $\geq 80 \mathrm{~cm}$ & - & - & - & - & 4.681 & $<0.01$ & 3.466 & 0.011 \\
\hline Blood glucose $\geq 100 \mathrm{mg} / \mathrm{dl}$ & - & - & - & - & 2.533 & 0.146 & * & * \\
\hline Triglycerides $\geq 150 \mathrm{mg} / \mathrm{dl}$ & - & - & - & - & 1.696 & 0.251 & * & * \\
\hline Total cholesterol $\geq 190 \mathrm{mg} / \mathrm{dl}$ & - & - & - & - & -2.271 & 0.096 & * & * \\
\hline \multicolumn{9}{|l|}{ Level 4: } \\
\hline \multicolumn{9}{|l|}{ Genotypes: } \\
\hline $\mathrm{GT}$ & - & - & - & - & - & - & 2.726 & 0.026 \\
\hline $\mathrm{TT}$ & - & - & - & - & - & - & 8.320 & $<0.01$ \\
\hline \multicolumn{9}{|l|}{ Diastolic blood pressure } \\
\hline \multicolumn{9}{|l|}{ Level 1: } \\
\hline Age group $\geq 30$ [years] & 3.413 & $<0.01$ & 3.248 & $<0.01$ & 1.981 & $<0.01$ & 2.049 & $<0.01$ \\
\hline Living in a rural area & 3.727 & 0.014 & 2.420 & 0.019 & 1.548 & 0.149 & 1.714 & 0.088 \\
\hline Education: $\leq 8$ years & 0.607 & 0.530 & * & * & $*$ & * & * & * \\
\hline Parity: $\geq 3$ children & 2.026 & 0.041 & 1.950 & 0.028 & 2.368 & 0.016 & 1.659 & 0.054 \\
\hline Access to health services: public & 0.657 & 0.709 & * & * & * & * & * & * \\
\hline Food insecurity: $\geq 1$ & 0.114 & 0.909 & * & * & * & * & * & * \\
\hline \multicolumn{9}{|l|}{ Level 2: } \\
\hline Became ill over the last 15 days & - & - & 0.025 & 0.976 & * & * & * & * \\
\hline Added salt intake & - & - & -1.752 & 0.119 & * & * & * & * \\
\hline Smoking & - & - & -2.135 & 0.130 & * & * & * & * \\
\hline \multicolumn{9}{|l|}{ Level 3: } \\
\hline Overweight (BMI $\left.\geq 25 \mathrm{~kg} / \mathrm{m}^{2}\right)$ & - & - & - & - & 3.002 & $<0.01$ & 2.797 & $<0.01$ \\
\hline Waist circumference $\geq 80 \mathrm{~cm}$ & - & - & - & - & 2.177 & 0.040 & 2.123 & 0.023 \\
\hline Blood glucose $\geq 100 \mathrm{mg} / \mathrm{dl}$ & - & - & - & - & -0.290 & 0.840 & * & * \\
\hline Triglycerides $\geq 150 \mathrm{mg} / \mathrm{dl}$ & - & - & - & - & 1.936 & 0.066 & * & * \\
\hline Total cholesterol $\geq 190 \mathrm{mg} / \mathrm{dl}$ & - & - & - & - & -1.293 & 0.188 & * & * \\
\hline \multicolumn{9}{|l|}{ Level 4: } \\
\hline \multicolumn{9}{|l|}{ Genotypes: } \\
\hline $\mathrm{GT}$ & - & - & - & - & - & - & 1.797 & 0.034 \\
\hline$\overline{\mathrm{TT}}$ & - & - & - & - & - & - & 4.694 & $<0.01$ \\
\hline
\end{tabular}


the profile of the population of the present study).

One limitation of the present study was the non-inclusion of men in the sample. This occurred because this work was part of a larger project called II Diagnosis of maternal and child health in the state of Alagoas, in which the focus was on children, adolescents and women of childbearing age. Some results obtained from this project are available elsewhere [40-46]. Therefore, considering the overall population of the state, the men and the elderly of both sexes were left out. For this study, as already explained, women between the ages of 19 and 49 were eligible. Thus, given the existing differences in the occurrence of hypertension according to gender, it is suggested to carry out additional studies that include male subjects.

In conclusion, the results indicate that the $T T$ genotype of the eNOS gene G894T polymorphism is significantly associated with a higher prevalence of hypertension and is an important risk factor for this disease, especially when it is associated with older age groups and excess body weight.

Considering that the mechanism of action that might cause women with the GT or TT genotype to present with higher BP levels involves less metabolic production of NO, the current findings suggest that this polymorphism is directly related to the regulation of BP and might be an important marker in the diagnosis of systemic hypertension.

\section{Conflict of interest}

The authors declare no conflict of interest.

\section{References}

1. Lim SS, Vos T, Flaxman AD, et al. A comparative risk assessment of burden of disease and injury attributable to 67 risk factors and risk factor clusters in 21 regions, 1990-2010: a systematic analysis for the Global Burden of Disease Study 2010. Lancet 2012; 380: 2224-60.

2. Weber MA, Schiffrin EL, White WB, et al. Clinical practice guidelines for the management of hypertension in the community: a statement by the American Society of Hypertension and the International Society of Hypertension. J Clin Hypertens (Greenwich) 2014; 16: 14-26.

3. Surendran P, Drenos F, Young R, et al. Trans-ancestry meta-analyses identify rare and common variants associated with blood pressure and hypertension. Nat Genet 2016; 48: 1151-61.

4. Ehret GB, Ferreira T, Chasman DI, et al. The genetics of blood pressure regulation and its target organs from association studies in 342,415 individuals. Nat Genet 2016; 48: 1171-84.

5. Gamboa A, Shibao C, Diedrich A, et al. Contribution of endothelial nitric oxide to blood pressure in humans. Hypertension 2007; 49: 170-7.

6. Otani $\mathrm{H}$. The role of nitric oxide in myocardial repair and remodeling. Antioxid Redox Signal 2009; 11: 1913-28.

7. Thomas GD, Zhang W, Victor RG. Nitric oxide deficiency as a cause of clinical hypertension: promising new drug targets for refractory hypertension. JAMA 2001; 285: 2055-7.

8. Huang PL, Huang Z, Mashimo H, et al. Hypertension in mice lacking the gene for endothelial nitric oxide synthase. Nature 1995; 377: 239-42.

9. Qian J, Fulton D. Post-translational regulation of endothelial nitric oxide synthase in vascular endothelium. Front Physiol 2013; 4: 347.

10. Naseem KM. The role of nitric oxide in cardiovascular diseases. Mol Aspects Med 2005; 26: 33-65.

11. Miyamoto Y, Saito Y, Kajiyama N, et al. Endothelial nitric oxide synthase gene is positively associated with essential hypertension. Hypertension 1998; 32: 3-8.

12. Goni L, Cuervo M, Milagro FI, Martinez JA. Influence of fat intake and BMI on the association of rs1799983 NOS3 polymorphism with blood pressure levels in an Iberian population. Eur J Nutr 2017; 56: 1589-96.

13. Sousa AC, Mendonça MI, Pereira A, et al. Synergistic association of genetic variants with environmental risk factors in susceptibility to essential hypertension. Genet Test Mol Biomarkers 2017; 21: 625-31.

14. Andrade SSA, et al. Prevalência de hipertensão arterial autorreferida na população brasileira: análise da Pesquisa Nacional de Saúde, 2013 [Self-reported hypertension prevalence in the Brazilian population: analysis of the National Health Survey, 2013.]. Epidemiologia e Serviços de Saúde, 2015; 24: 297-304.

15. Costa NS, Santos MO, Carvalho CPO, Assunção ML, Ferreira HS. Prevalence and factors associated with food insecurity in the context of the economic crisis in Brazil. Curr Dev Nutr 2017; 1:e000869.

16. Pimenta AM, Gazzinelli A, Velásquez-Meléndez G. Prevalência da síndrome metabólica e seus fatores associados em área rural de Minas Gerais (MG, Brasil) [Prevalence of metabolic syndrome and its associated factors in a rural area of Minas Gerais State (MG, Brazil)]. Ciência \& Saúde Coletiva 2011; 16: 3297-306.

17. Chobanian AV, Bakris GL, Black HR, et al. Seventh report of the Joint National Committee on prevention, detection, evaluation, and treatment of high blood pressure. Hypertension 2003; 42: 1206-52.

18. Abrao MG, Billerbeck AE, Nishi MY, Marui S, Mendonca BB. Standardization of DNA extraction with $\mathrm{NaCl}$ from oral mucosa cells: application in PROP1 gene study. Arq Bras Endocrinol Metabol 2005; 49: 978-82.

19. Martin SS, Blaha MJ, Elshazly MB, et al. Comparison of a novel method vs the Friedewald equation for estimating low-density lipoprotein cholesterol levels from the standard lipid profile. JAMA 2013; 310: 2061-8.

20. Sturmer G, Dias-da-Costa JS, Olinto MT, et al. Non-pharmacological management of hypertension in Southern Brazil. Cad Saude Publica 2006; 22: 1727-37.

21. Saini V, Bhatnagar MK, Bhattacharjee J. Association of endothelial dysfunction with endothelin, nitric oxide and eNOS Glu298Asp gene polymorphism in coronary artery disease. Dis Markers 2011; 31: 215-22.

22. Hillermann R, Carelse K, Gebhardt GS. The Glu298Asp variant of the endothelial nitric oxide synthase gene is associated with an increased risk for abruptio placentae in pre-eclampsia. J Hum Genet 2005; 50: 415-9.

23. Li R, Lyn D, Lapu-Bula R, et al. Relation of endothelial nitric oxide synthase gene to plasma nitric oxide level, endothelial function, and blood pressure in African Americans. Am J Hypertens 2004; 17: 560-7.

24. Gad MZ, Abdel Rahman MF, Hashad IM, et al. Endothelial nitric oxide synthase (G894T) gene polymorphism in a random sample of the Egyptian population: compari- 
son with myocardial infarction patients. Genet Test Mol Biomarkers 2012; 16: 695-700.

25. Moon J, Yoon S, Kim E, Shin C, Jo SA, Jo I. Lack of evidence for contribution of Glu298Asp (G894T) polymorphism of endothelial nitric oxide synthase gene to plasma nitric oxide levels. Thromb Res 2002; 107: 129-34.

26. Nishevitha NS, Angeline T, Jeyaraj N. Endothelial nitric oxide synthase (eNOS) Glu298-->Asp polymorphism (G894T) among south Indians. Indian J Med Res 2009; 129: 68-71.

27. Picon RV, Fuchs FD, Moreira LB, Fuchs SC. Prevalence of hypertension among elderly persons in urban Brazil: a systematic review with meta-analysis. Am J Hypertens 2013; 26: 541-8.

28. Malta DC, Szwarcwald CL. Lifestyles and chronic non-transmissible diseases of the Brazilian population according to the National Health Survey: balance of the main results. Sao Paulo Med J 2015; 133: 286-9.

29. Instituto Brasileiro de Geografia e Estatística (IBGE). Pesquisa Nacional de Saúde 2013 [Health National Survey 2013]. Percepção do estado de saúde, estilos de vida e doenças crônicas. 2014 November 05, 2017]; Available from: ftp://ftp.ibge.gov.br/PNS/2013/pns2013.pdf.

30. Xie X, Shi X, Xun X, Rao L. Endothelial nitric oxide synthase gene single nucleotide polymorphisms and the risk of hypertension: a meta-analysis involving 63,258 subjects. Clin Exp Hypertens 2017; 39: 175-182.

31. Niu W, Qi Y. An updated meta-analysis of endothelial nitric oxide synthase gene: three well-characterized polymorphisms with hypertension. PLoS One 2011; 6: e24266.

32. Rai H, Parveen F, Kumar S, Kapoor A, Sinha N. Association of endothelial nitric oxide synthase gene polymorphisms with coronary artery disease: an updated meta-analysis and systematic review. PLoS One 2014; 9: e113363.

33. Qin J, Dai J, Xu Z, et al. Genetic polymorphism of NOS3 with susceptibility to deep vein thrombosis after orthopedic surgery: a case-control study in Chinese Han population. PLoS One 2013; 8: e70033.

34. Abdel-Aziz TA, Mohamed RH. Association of endothelial nitric oxide synthase gene polymorphisms with classical risk factors in development of premature coronary artery disease. Mol Biol Rep 2013; 40: 3065-71.

35. Persu A, Stoenoiu MS, Messiaen T, et al. Modifier effect of ENOS in autosomal dominant polycystic kidney disease. Hum Mol Genet 2002; 11: 229-41.

36. Tesauro M, Thompson WC, Rogliani P, Qi L, Chaudhary PP, Moss J. Intracellular processing of endothelial nitric oxide synthase isoforms associated with differences in severity of cardiopulmonary diseases: cleavage of proteins with aspartate vs. glutamate at position 298. Proc Natl Acad Sci USA 2000; 97: 2832-5.

37. Kayhan FE, Koldemir M, Cagatay P, Ciftci C, Susleyici-Duman B. Prevalence of endothelial nitric oxide synthase E298D polymorphism in Turkish patients with essential hypertension. Diabetes Metab Syndr 2013; 7: 12-6.

38. Sawada T, Kishimoto T, Osaki Y, et al. Relation of the Glu298Asp polymorphism of the nitric oxide synthase gene to hypertension and serum cholesterol in Japanese workers. Prev Med 2008; 47: 167-71.

39. da Cunha NV, Pinge-Filho P, Panis C, et al. Decreased endothelial nitric oxide, systemic oxidative stress, and increased sympathetic modulation contribute to hypertension in obese rats. Am J Physiol Heart Circ Physiol 2014; 306: H1472-80.

40. Caminha TC, Ferreira HS, Costa NS, et al. Waist-toheight ratio is the best anthropometric predictor of hy- pertension: a population-based study with women from a state of northeast of Brazil. Medicine 2017; 96: e5874.

41. Costa NS, Santos MO, Carvalho CPO, Assunção ML, Ferreira HS. Prevalence and factors associated with food insecurity in the context of the economic crisis in Brazil. Curr Dev Nutr 2017; 1: e000869.

42. Lima RB. Coverage and educational actions related to the national vitamin A supplementation program: a study in children from the state of Alagoas. J Pediatr 2018 pii: S0021-7557(18)30542-4. doi: 10.1016/j.jped. 2018.08.006.

43. da Silva Ferreira H, Xavier Jr AFS, Assunção ML, Caminha Uchôa TC, Lira-Neto AB, Nakano RP. Developmental origins of health and disease: a new approach for the identification of adults who suffered undernutrition in early life. Diabetes Metab Syndr Obes 2018; 11: 543-51.

44. Nakano RP, Caminha TC, Xavier Jr AF, De Assunção ML, Ferreira $\mathrm{H}$. Prevalence, temporal trend and associated factors with excess body weight in mothers of children under five years. Revista de Nutrição 2018; 31: 159-73.

45. Sotero AM, da S. Ferreira H, Assunção ML, de Lira PIC. Pre-gestational excessive weight and duration of breast-feeding. Public Health Nutr 2018; 21: 309-16.

46. da Silva Vieira RC. Prevalence and temporal trend (2005-2015) of anaemia among children in Northeast Brazil. Public Health Nutr 2018; 21: 868-76. 